Western North American Naturalist 68(3), (C) 2008, pp. 350-364

\title{
A 2000-YEAR ENVIRONMENTAL HISTORY OF JACKSON HOLE, WYOMING, INFERRED FROM LAKE-SEDIMENT RECORDS
}

\author{
Karen Jacobs ${ }^{1}$ and Cathy Whitlock ${ }^{1,2}$
}

\begin{abstract}
Little is known about the disturbance history of low-elevation forest and steppe vegetation in the western United States, nor about the relative importance of climate and human activity in shaping present-day plant communities. We analyzed pollen and high-resolution macroscopic charcoal records spanning the last 2100, 1000, and 550 cal years from 3 small lakes in Jackson Hole, Wyoming, to reconstruct the vegetation and fire history along a gradient from steppe to dry forest. The pollen data suggest little change in vegetation in the last 2 millennia, aside from a long-term trend toward more forest at the expense of steppe. One site showed an expansion of mesophytic taxa in the last 350 years as a result of local changes in hydrology, and another site was dry prior to AD 1000 and showed fluctuations in steppe composition thereafter. The longest record suggests that fire frequency was higher before AD 1200 than after. Comparison of 3 charcoal records for the last 550 years indicates widespread fire episodes in AD 1980-2000, 1780-1810, ca. 1550, and $1420-1430$. Changes in the vegetation and fire history of the last 2000 years show a response to effectively drier conditions prior to AD 1200 and wetter conditions during the Little Ice Age. Evidence of human influences was muted at best. Native Americans apparently did not alter the vegetation and fire regimes significantly during their occupation of Jackson Hole. Euro-American activities also had minor registration in the paleoecologic record: humans may have been directly responsible for fires in the mid- and late 19th century and indirectly responsible for the recent expansion of forest at the end of the 20th century.
\end{abstract}

Key words: Grand Teton National Park, fire history, vegetation history, last 2000 years.

Evaluating present-day forest health in the western United States requires an understanding of the natural variability of ecological processes, including the long-term impact of climate change and natural disturbances on plant communities (Whitlock et al. 2003, McKenzie et al. 2004), as well as the role of past and present human activity. The last 2000 years is often used as a reference period to assess modern ecosystem conditions because comprehensive tree-ring data provide independent climate information during this time (Cook et al. 2004), and it is possible to examine ecological response to well-documented climate events, such as the Medieval Climate Anomaly (ca. AD 900-1300; Hughes and Diaz 1994, Pierce et al. 2004) and the Little Ice Age (ca. AD 1350-1850; Carrara 1989, Luckman 2000). In addition, this period provides an opportunity to consider the impact of Native American and Euro-American activities on vegetation and fire regimes.

Grand Teton National Park (GTNP) in northwestern Wyoming protects a region of rugged mountains, pristine lakes, and a rich native fauna and flora (Fig. 1). The vegetation is arrayed by elevation, with sagebrush (Arte- misia tridentata) steppe growing below approximately $2000 \mathrm{~m}$ elevation on the valley floor of Jackson Hole (botanical nomenclature follows Shaw [2000] and references therein). At high elevations (2000-2400 m elevation) in the Teton and Gros Ventre Ranges, steppe is replaced by forests of lodgepole pine (Pinus contorta) and Douglas-fir (Pseudotsuga menziesii). Engelmann spruce (Picea engelmannii), subalpine fir (Abies lasiocarpa), and whitebark pine (P. albicaulis) grow at higher, more mesic elevations (2400-2900 m elevation) and form the upper treeline. Alpine meadows and tundra lie above approximately $2900 \mathrm{~m}$ elevation on the highest peaks of the Teton Range (Clark 1981).

Historical and archeological data show a long history of human occupation of the valley. Early native encampments are recorded throughout the Holocene, and shifts have been noted in their use of the valley during the late Holocene (Connor 1998). Euro-Americans have been in the region for the last 200 years (Daugherty 1999), first as trappers and miners, then as ranchers, and most recently as tourists and recreationalists. Grand Teton National Park was first established in 1929 and included only the Teton Range and the large, glacially dammed

${ }^{1}$ Department of Earth Sciences, Montana State University, Bozeman MT 59717.

2Corresponding author. E-mail: whitlock@montana.edu 


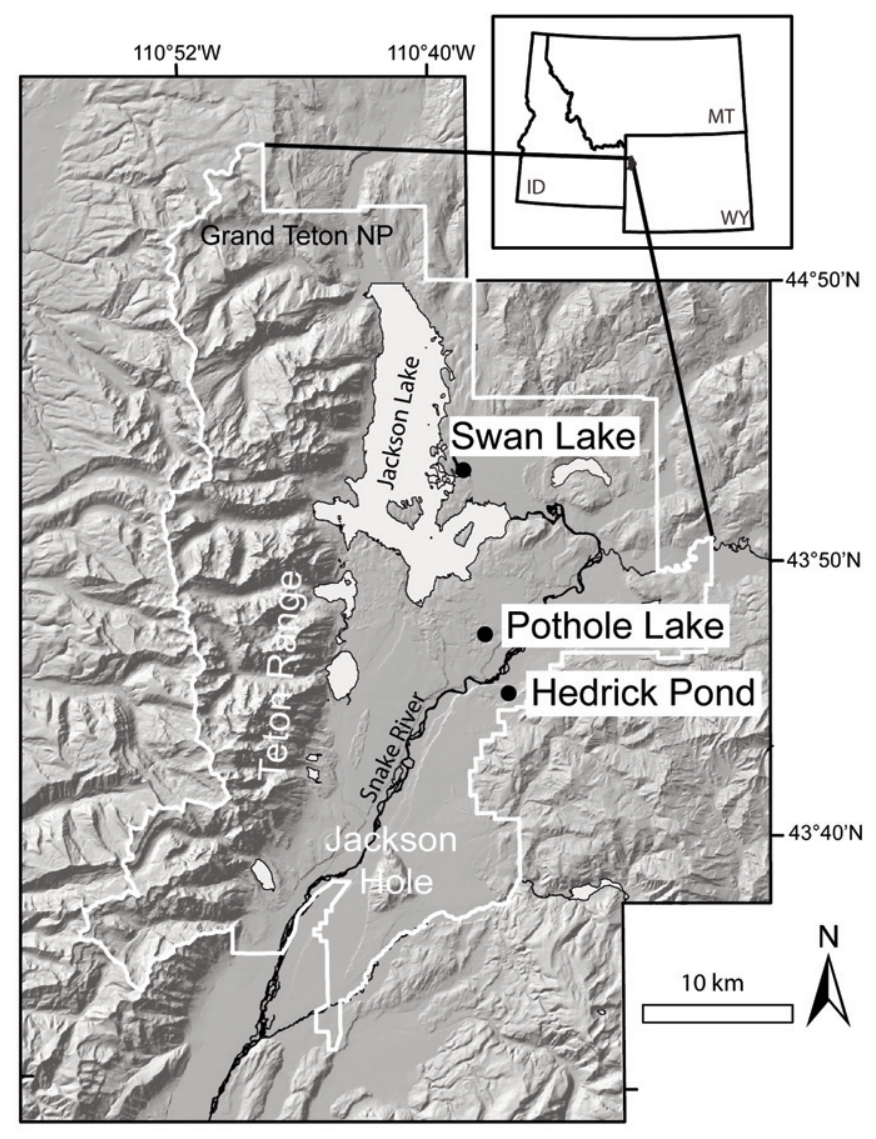

Fig. 1. Map of Grand Teton National Park, showing study sites.

lakes at the mountain front. Later, Jackson Hole National Monument and other land parcels were included, and the present national park was established in 1950 (Daugherty 1999).

The postglacial vegetation and climate history of the Grand Teton and Yellowstone region have been described in Baker (1976) and Whitlock (1993), but the history of the lowelevation dry forest and steppe in Jackson Hole has been poorly studied. To fill this gap, we developed an environmental history of the last 2100 years based on paleoecologic data obtained from the sediments of 3 small lakes. Pollen, charcoal, and lithologic records from each site permitted a reconstruction of local changes in vegetation, fire regimes, and hydrology that could be compared with climate and human-impact data from other sources. The lakes were selected along a north-south transect within Jackson Hole to capture a range of habitats (Fig. 1).
Swan Lake $\left(43.89^{\circ} \mathrm{N}, 110.63^{\circ} \mathrm{W}\right.$, elevation $2072 \mathrm{~m}$ ) is located on late Pinedale ground moraine and is the wettest site with the most extensive forest cover. The site is surrounded by closed lodgepole pine forest, but sagebrush steppe and meadow communities grow in forest openings and on the Pilgrim Creek alluvial fan to the south and east of the site. The fan dams the lake and supports a large riparian community of Engelmann spruce, blue spruce (Picea pungens), subalpine fir, willow (Salix spp.), and thinleaf alder (Alnus incana) to the east.

Pothole Lake $\left(43.78^{\circ} \mathrm{N}, 110.62^{\circ} \mathrm{W}\right.$, elevation $2033 \mathrm{~m}$ ) is located in the center of Jackson Hole and represents the driest site. Sagebrushsteppe communities surround the site and are the dominant plant community of Jackson Hole as a result of well-drained, gravelly glacial outwash of late Pinedale age (Good and Pierce 1996). Scattered exposures of glacial till 
near Pothole Lake support stands of Douglasfir and lodgepole pine, and springs support local wetland and aspen (Populus tremuloides) communities.

Hedrick Pond $\left(43.73^{\circ} \mathrm{N}, 110.59^{\circ} \mathrm{W}\right.$, elevation $2048 \mathrm{~m}$ ) lies near the boundary between forest in the Gros Ventre Range to the east and sagebrush steppe in Jackson Hole to the west. It is considered a transitional site in the moisture gradient between Swan and Pothole Lakes. The steep slopes and morainal soils favor forests of lodgepole pine and lesser amounts of Douglas-fir, subalpine fir, and common juniper (Juniperus communis). The well-drained glacial outwash to the south of Hedrick Pond and forest openings support steppe vegetation and meadow communities. Populus tremuloides (quaking aspen) stands grow near wet seepages.

\section{Methods}

\section{Field}

In 2005 we collected sediment cores with a 5 -cm-diameter modified Livingstone squarerod piston sampler (Wright et al. 1983) in the deepest portion of each lake from the ice surface in winter and from an anchored floating platform in summer. Cores were extruded in the field, wrapped in plastic wrap and aluminum foil, and taken to the Montana State University Paleoecology Lab where they were refrigerated. In addition, we took short sediment cores from each site with a 7 -cm-diameter Klein piston corer to recover the mud-water interface and the upper half-meter of sediment. Each short core was subsampled in the field at $1-\mathrm{cm}$ intervals, and samples were stored in Whirlpak ${ }^{\circledR}$ bags and refrigerated.

\section{Laboratory}

Loss-on-ignition (LOI) analysis was undertaken to measure the organic and carbonate content of the sediment and provide information on lake productivity (Dean 1974). We took LOI samples of $1-\mathrm{cm}^{3}$ volume at contiguous 1$\mathrm{cm}$ intervals to a depth of $20 \mathrm{~cm}$ and at every other centimeter down to $60 \mathrm{~cm}$ in the Hedrick Pond short core. In the long core, samples were taken every $5 \mathrm{~cm}$. In the Pothole Lake short core, we sampled contiguous 1-cm intervals to a depth of $14 \mathrm{~cm}$ and 2-cm intervals down to $66 \mathrm{~cm}$. At Swan Lake, contiguous 1-cm intervals were sampled to a depth of $8 \mathrm{~cm}$ in the short core and at 5 - $\mathrm{cm}$ intervals in the long core. Samples were dried at $90^{\circ} \mathrm{C}$ for 24 hours and ashed for 2 hours at $550^{\circ} \mathrm{C}$ and then 2 hours at $900^{\circ} \mathrm{C}$. Weight loss after each treatment was used to calculate percentage of dry weight, organic content, and carbonate content, respectively (Dean 1974).

Magnetic susceptibility, an indicator of deposition of mineral soil or fire-created detrital magnetite or maghemite (Thompson and Oldfield 1986), was measured with a Bartington MS2 magnetic susceptibility cup sensor and ring sensor. Contiguous $10-\mathrm{cm}^{3}$ samples were analyzed in the long and short cores from Hedrick Pond and Swan Lake with a cup sensor, and $10-\mathrm{cm}^{3}$ samples were analyzed at 2 $\mathrm{cm}$ intervals with a ring sensor in the Pothole Lake core.

\section{Charcoal}

We performed macroscopic charcoal analysis on contiguous 1-cm-interval samples to reconstruct the local fire history for each site, following the modified sieving approach of Whitlock and Larsen (2001). Samples of $3 \mathrm{~cm}^{3}$ (Hedrick Pond and Swan Lake) and $4 \mathrm{~cm}^{3}$ (Pothole Lake) were soaked in a solution of 5\% sodium metaphosphate and 6\% bleach for 24 hours and then washed through nested sieves (mesh size 250 and $125 \mu \mathrm{m}$ ). Charcoal particles $>125 \mu \mathrm{m}$ in minimum diameter were examined because they have been shown to record local fire activity (Whitlock and Larsen 2001). After placing residues in a gridded petri dish, we identified them under a stereoscope at 120X and 250X magnification. Charcoal counts were divided by sample volume to calculate charcoal concentrations (particles $\cdot \mathrm{cm}^{-3}$ ). We then interpolated concentrations and sedimentation rates to pseudo-annual values and binned them in 10-yr-long intervals. Charcoal accumulation rates (CHAR; particles $\cdot \mathrm{cm}^{-2} \mathrm{yr}^{-1}$ ) were calculated by dividing charcoal concentration by the deposition time of the sediment $\left(\mathrm{yr} \cdot \mathrm{cm}^{-1}\right)$. Interpolation of concentration values to pseudo-annual values, followed by binning and calculation of CHAR, preserved the total number of particles accumulated over time. We used CHAPS software (P.J. Bartlein, Univ. Oregon, unpublished) for the charcoal analysis.

$$
\text { Pollen }
$$

We took pollen samples at 4- to 6-cm intervals at Hedrick Pond, 4-cm intervals at Pothole Lake, and 3-cm intervals at Swan Lake. These 
TABLE 1. Structural classes based on stem recruitment, stem exclusion, number of age cohorts, and cohort age.

\begin{tabular}{|c|c|c|c|c|}
\hline Depth (m)a & $\begin{array}{l}\text { Uncalibrated }{ }^{14} \mathrm{C} \\
\text { age }\left({ }^{(14} \mathrm{C} \text { yr BP }\right)\end{array}$ & $\begin{array}{c}\text { Calibrated age (cal yr BP) } \\
\text { with } 2 \text { sigma rangeb }\end{array}$ & Material dated & Lab numberc \\
\hline \multicolumn{5}{|c|}{ Hedrick Pond } \\
\hline 0.69 & $700 \pm 40$ & $575, \mathbf{6 6 6}, 580,664,706,720(559-721)$ & Conifer needle & LL119626 \\
\hline 1.37 & $2209 \pm 39$ & $2182,2247,2301,2236(2140-2333)$ & Unidentified leaf & AA63992 \\
\hline \multicolumn{5}{|l|}{ Pothole Lake } \\
\hline 0.33 & $290 \pm 40$ & $314,364,400.5,160.5,376(155-467)$ & Unidentified leaf & LL119627 \\
\hline 0.48 & $1090 \pm 50$ & 986.5, 1039, 1008.5, 1121.5, $1164.5(924-1167)$ & Unidentified leaf & LL119625 \\
\hline \multicolumn{5}{|c|}{ 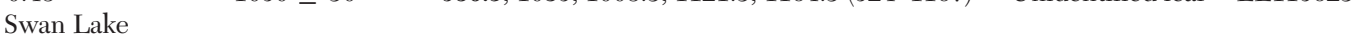 } \\
\hline 0.70 & $455 \pm 35$ & $\mathbf{5 1 1 . 5}, 344.5,501.5(343-541)$ & Wood bark & LL119624 \\
\hline
\end{tabular}

Age Models (including ${ }^{210} \mathrm{~Pb}$ dates) $)^{\mathrm{d}}$

Hedrick Pond

Age $($ cal yr BP $)=-0.0002 \cdot \operatorname{depth}^{3}+0.1212 \cdot \operatorname{depth}^{2}+2.9296 \cdot \operatorname{depth}-56.605\left(r^{2}=0.999\right)$

Pothole Lake

Age $($ cal yr BP $)=0.0038 \cdot \operatorname{depth}^{3}+0.2122 \cdot \operatorname{depth}^{2}+2.6524 \cdot \operatorname{depth}-55.009\left(r^{2}=0.999\right)$

Swan Lake $(0-59$ cal yr BP)

Age $^{\mathrm{e}}=0.0263 \cdot \operatorname{depth}^{4}-0.3565 \cdot \operatorname{depth}^{3}+1.2818 \cdot \operatorname{depth}^{2}+1.7373 \cdot \operatorname{depth}-52.824\left(r^{2}=0.9987\right)$

Swan Lake $(59-550$ cal yr BP)

Age $^{\mathrm{f}}=8.1441 \cdot$ depth -58.585

aDepth below mud surface.

b ${ }^{14} \mathrm{C}$ ages derived from CALIB 5.0.2 calibration curves (Stuiver et al. 1998). In some cases, multiple ages were possible if the sample crossed multiple points along the calibration curve. In these cases, the mean age with the greatest area under the probability curve was used in the age model (bolded age). The 2 sigma age range is given in parentheses.

cAA - University of Arizona AMS Facility; LL - Lawrence Livermore National Laboratory

d $210 \mathrm{~Pb}$ dates were adjusted for the 55 years (the cores were taken in 2005) since $1950 \mathrm{AD}$ in order to compare them with the calibrated radiocarbon dates.

e The Swan Lake age model between 0 and $59 \mathrm{cal}$ yr BP was based on ${ }^{210} \mathrm{~Pb}$ dates only (Table 2 ).

fThe Swan Lake age model prior to $59 \mathrm{cal}$ yr BP was based on calibrated ${ }^{14} \mathrm{C}$ ages and only the oldest ${ }^{210} \mathrm{~Pb}$ date.

samples were then processed following methods of Faegri et al. (1989), but using Schulze's solution in place of acetolysis (see Doher 1980). Pollen preparations were mounted in silicone oil and examined under magnifications of 400X and 1000X. Identifications were based on a comparison of published atlases and keys (e.g., Moore and Webb 1978, Kapp et al. 2000). Whenever the distal membrane was preserved, pine pollen was separated into diploxylon-type (Pinus contorta) and haploxylon-type (P.flexilis, $P$. albicaulis). The addition of unidentifiable Pinus grains yielded total Pinus. We designated grains that could not be identified as unknown $(<1 \%$ of total pollen in all samples); those that were deteriorated, corroded, or severely broken were designated as degraded (not shown on diagram).

We tallied percentages of terrestrial pollen types based on the sum of all terrestrial taxa. Percentages of aquatic taxa were based on the sum of all terrestrial, aquatic, and wetland taxa. Pollen records were zoned using CONISS, a constrained cluster analysis (Grimm 1987) of the dominant taxa in the percentage data. A known amount of Lycopodium spores was added as a "spike" to each sample in order to calculate pollen concentrations (pollen $\cdot \mathrm{cm}^{-3}$ ).
To calculate pollen accumulation rates (PAR; pollen $\cdot \mathrm{cm}^{-2} \mathrm{yr}^{-1}$, we divided concentration data by the calculated deposition time ( $\mathrm{yr}$. $\mathrm{cm}^{-1}$ ) of each sample.

\section{RESUlTS}

\section{Lithology and Chronology}

We based chronologies for the sites on a series of AMS ${ }^{14} \mathrm{C}$ and ${ }^{210} \mathrm{~Pb}$ dates taken on terrestrial plant macrofossils (Tables 1 and 2). Radiocarbon ages were converted to calendar years using the CALIB program of Stuiver et al. (1998). This suite of age determinations was fitted with a polynomial to develop a smooth age-depth model. Calibration of ${ }^{14} \mathrm{C}$ dates yielded multiple age possibilities in most cases, and the mean age with the highest probability was used. ${ }^{210} \mathrm{~Pb}$ dates have errors of years (for the youngest) to decades (for the oldest) in general. Specific ages were based on the polynomial regression, but it is important to recognize that the error around age assignments ranges from years to decades. Throughout the results and discussion, ages $<950 \mathrm{cal} \mathrm{yr}$ BP are presented first in years AD.

At Hedrick Pond we recovered a $137-\mathrm{cm}-$ long core beneath $4.70 \mathrm{~m}$ of water. The sedi- 
TABLE 2. Short core ${ }^{210} \mathrm{~Pb}$ concentrations and age determinations $s^{\mathrm{a}}$.

\begin{tabular}{cccc}
\hline & $\begin{array}{c}\text { Depth } \\
(\mathrm{cm})^{\mathrm{b}}\end{array}$ & 210 $\mathrm{Pb} \mathrm{dpm} \cdot \mathrm{g}^{-1}$ & $\begin{array}{c}\text { Age } \\
\text { (year AD) }\end{array}$ \\
\hline Hedrick Pond & & & \\
& $0-1$ & 67.57 & 2003 \\
$1-2$ & 43.10 & 2001 \\
& $2-3$ & 38.64 & 1999 \\
$3-4$ & 28.38 & 1997 \\
$4-5$ & 33.79 & 1994 \\
$5-6$ & 34.70 & 1991 \\
$6-7$ & 30.98 & 1987 \\
$7-8$ & 29.74 & 1984 \\
$8-9$ & 14.88 & 1980 \\
$9-10$ & 19.45 & 1977 \\
$10-11$ & 12.90 & 1973 \\
$11-12$ & 21.74 & 1968 \\
$12-13$ & 17.16 & 1954 \\
$14-15$ & 7.44 & 1919
\end{tabular}

Pothole Lake

$\begin{array}{crr}0-1 & 47.67 & 2003 \\ 1-2 & 28.13 & 2001 \\ 2-3 & 31.81 & 1999 \\ 3-4 & 31.01 & 1996 \\ 4-5 & 36.03 & 1992 \\ 5-6 & 32.68 & 1986 \\ 6-7 & 21.73 & 1981 \\ 7-8 & 18.83 & 1976 \\ 8-9 & 15.31 & 1970 \\ 9-10 & 12.62 & 1965 \\ 10-11 & 12.27 & 1955 \\ 12-13 & 8.93 & 1927\end{array}$

Swan Lake

$\begin{array}{ccc}0-1 & 72.02 & 2003 \\ 1-2 & 60.61 & 2000 \\ 2-3 & 36.02 & 1996 \\ 3-4 & 22.04 & 1994 \\ 4-5 & 22.18 & 1992 \\ 5-6 & 16.83 & 1991 \\ 6-7 & 14.81 & 1988 \\ 7-8 & 10.18 & 1986 \\ 8-9 & 28.09 & 1983 \\ 9-10 & 26.27 & 1972 \\ 10-11 & 16.16 & 1950 \\ 11-12 & 20.62 & 1919\end{array}$

${ }^{a}$ Concentration age determinations provided by Dr. James Budahn at the U.S. Geological Survey, Denver, CO.

bDepth below mud surface.

ments consisted of homogeneous fine detritus gyttja (Fig. 2). Two AMS ${ }^{14} \mathrm{C}$ dates (Table 1) were obtained on terrestrial plant macrofossils from 69 and $137 \mathrm{~cm}$ depth (below mud surface). Fourteen ${ }^{210} \mathrm{~Pb}$ dates were obtained from the top $14 \mathrm{~cm}$ of the core (Table 2 ). The AMS ${ }^{14} \mathrm{C}$ and ${ }^{210} \mathrm{~Pb}$ dates were fitted with a 3 rd-order polynomial age-depth model, which dated the base of the core at $2182 \mathrm{cal} \mathrm{yr}$ BP. The organic content of the Hedrick Pond core varied between $40 \%$ and $60 \%$, and $\mathrm{CaCO}_{3}$ content was $<10 \%$ (Fig. 2). Magnetic susceptibility was very low through the core, and variations in values were not associated with those in charcoal concentration, as was found at sites in Yellowstone National Park (e.g., Millspaugh and Whitlock 1995, Millspaugh et al. 2000).

At Pothole Lake a 66-cm-long short core was recovered from beneath $2.10 \mathrm{~m}$ of water. The base of the core was crumbly, silty clay with fine rootlets that appeared to be a buried soil. It was overlain by silty detritus gyttja (17-65 cm depth), which graded upward into a fine detritus gyttja. An inorganic clay unit was present from 15 to $25 \mathrm{~cm}$ depth. Two AMS ${ }^{14} \mathrm{C}$ dates were obtained at 33 and $48 \mathrm{~cm}$ depth (Table 1). Twelve ${ }^{210} \mathrm{~Pb}$ dates were obtained from the top $12 \mathrm{~cm}$ of the core (Table 2). A 3rd-order polynomial age-depth model was fitted to the AMS ${ }^{14} \mathrm{C}$ and ${ }^{210} \mathrm{~Pb}$ dates. With the above data, we extrapolated the base of the core to 2136 cal yr BP, but the limnic part of the record analyzed in this study began at ca. 990 cal yr BP (48 cm depth).

Organic content in the Pothole Lake core varied between $25 \%$ and $40 \%$. The $\mathrm{CaCO}_{3}$ content was generally $<10 \%$ except for a peak $(15 \%)$ at $8 \mathrm{~cm}$ depth. Low organic content and high magnetic susceptibility were associated with the clay unit. Magnetic susceptibility was high from 66 to $50 \mathrm{~cm}$ depth, suggesting high input of allochthonous inorganic material to the lake. The shift to limnic sediments (i.e., gyttja and clay) at 990 cal yr BP marks the time when the basin held water year-round.

At Swan Lake a 73-cm-long core was recovered from beneath $3.30 \mathrm{~m}$ of water. The core consisted of dark brown clay with roots at its base (60-73 cm depth), overlain by gray-brown clay (29-60 cm depth) and fine detritus gyttja (0-29 cm depth). An AMS ${ }^{14} \mathrm{C}$ date from the clay unit yielded an age of 510 cal yr BP, and $12{ }^{210} \mathrm{~Pb}$ dates were obtained from the top 12 $\mathrm{cm}$ of the core (Tables 1 and 2). The age-depth model based on the ${ }^{210} \mathrm{~Pb}$ dates was incongruent with that based on the AMS ${ }^{14} \mathrm{C}$ date. Therefore, we used a 4th-order polynomial age model based on the ${ }^{210} \mathrm{~Pb}$ dates for the top 12 samples, and a linear model that included the oldest ${ }^{210} \mathrm{~Pb}$ date and the AMS ${ }^{14} \mathrm{C}$ date for the remainder of the core. The base of the Swan Lake core was linearly interpolated to $540 \mathrm{cal}$ yr BP. 

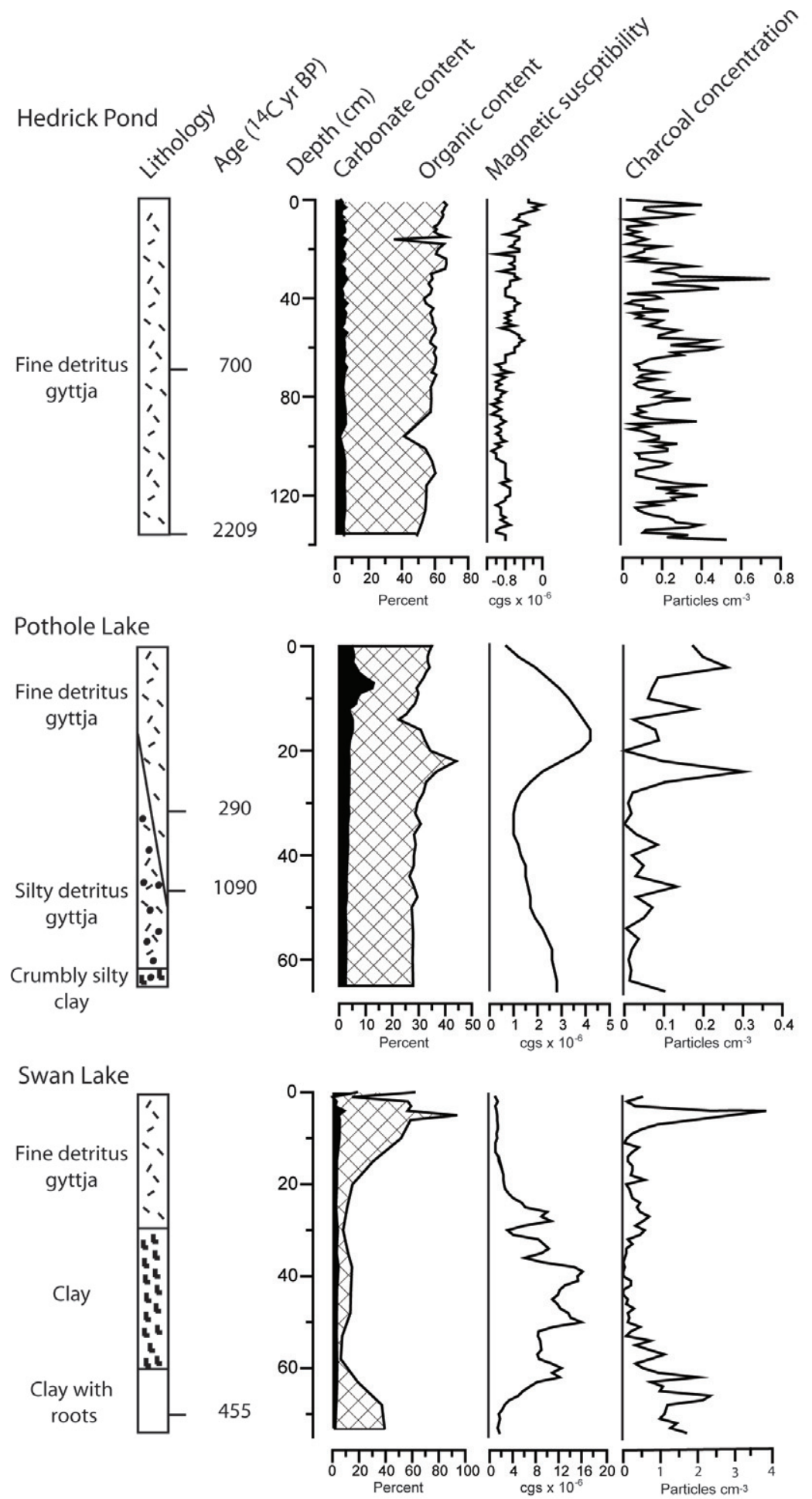

Fig. 2. Core lithology, radiocarbon ages, carbonate and organic content, magnetic susceptibility, and charcoal concentration for the study sites. MS units were expressed as cgs $\cdot 10^{-6}$. 


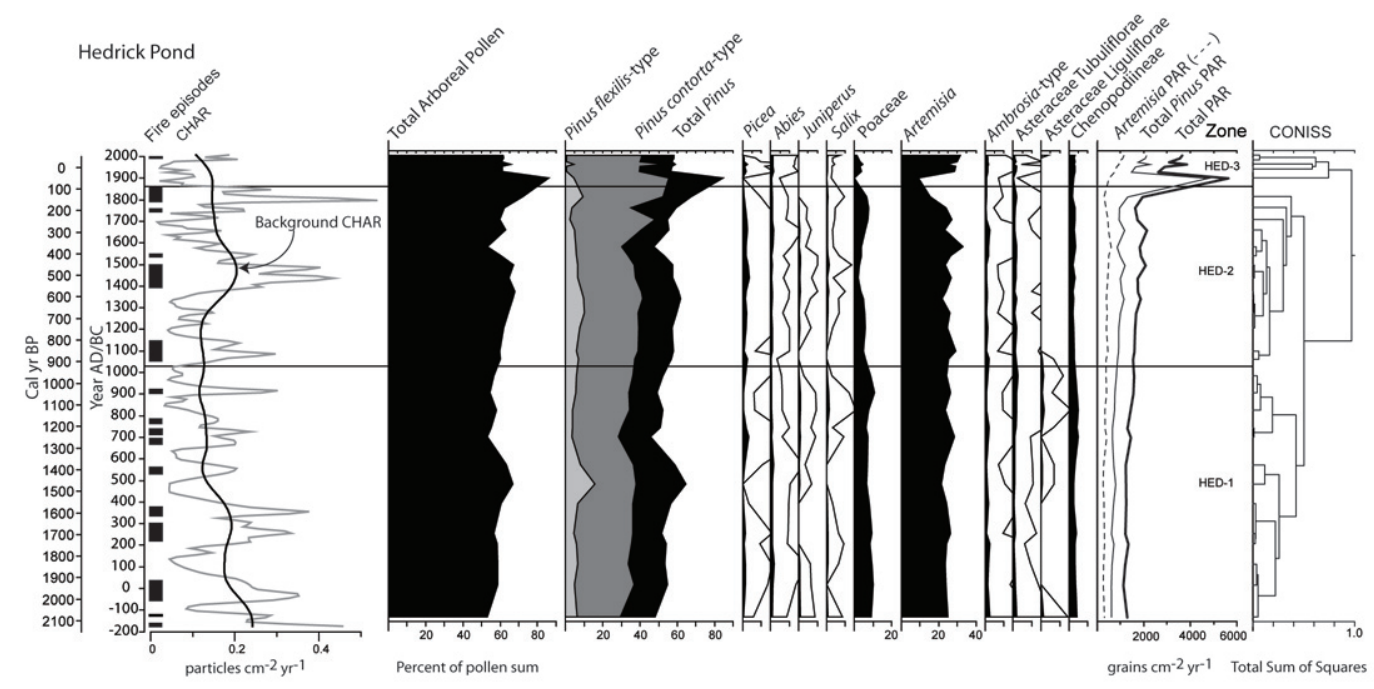

Fig. 3. Charcoal and pollen records of the last 2100 years at Hedrick Pond. Charcoal accumulation rates (CHAR) were decomposed into background (the slowly varying black line overlying the accumulation rate curve in gray). Fire episodes (black rectangles) at left are decades with higher-than-average fire (charcoal accumulation peaks above the threshold value). Pollen percentages of selected taxa and the pollen accumulation rates of Artemisia, total Pinus and total terrestrial pollen are shown. Outlined area on pollen curves is a 10X exaggeration of percentage data. CONISS dendrogram (at right) was used to define pollen zones.

Organic content in the Swan Lake core varied between $10 \%$ and $90 \%$. $\mathrm{CaCO}_{3}$ content was $<10 \%$. A significant drop in organic content between 20 and $60 \mathrm{~cm}$ depth and a rise in magnetic susceptibility were associated with the gray-brown clay unit. The clay is attributed to the creation of the lake, which was dammed by the build-up of the Pilgrim Creek alluvial fan (K. Pierce, unpublished data, 2007). Occasional overbank flood events during this buildup period spilled water into Swan Lake from the Pilgrim Creek drainage and deposited the clay.

\section{Charcoal Records}

The CHAR time series were divided into 2 components (Long et al. 1998). Background CHAR (BCHAR), or the low-frequency, slowly varying component, was determined using a locally weighted (moving) average through the time series, where the width of the weight function (window width) controlled the smoothness of the curve. For all sites, a standard window width of 500 years was used to calculate BCHAR to match other studies in the region, and variations in BCHAR were ascribed to changes in regional fire activity and fuel biomass (Marlon et al. 2006). BCHAR at all sites showed little change through time, consistent with the pollen data (see below). The values, however, were highest overall in the most mesic site (Swan Lake) and lowest in the steppe site (Pothole Lake), and this difference probably reflected the higher fuel biomass in the more forested location.

We interpreted positive deviations of CHAR (i.e., charcoal peaks) above BCHAR as charcoal accumulation during 1 or more local fires (socalled fire episodes). The peaks were identified as levels that exceeded a prescribed threshold ratio of total CHAR to BCHAR (a threshold ratio of 1.0, for example, would identify all CHAR peaks that exceed the BCHAR level as fire episodes). We used a threshold ratio of 1.15 in this study because it produced charcoal peaks that corresponded in time with known fires in the vicinity of each site (Loope 1974; Grand Teton National Park Fire Management Office, unpublished data, 2006). The ratio also resulted in few spurious charcoal episodes in the uppermost record (i.e., ones that did not match known fires). Unlike other studies that consider the fire episode to represent a single time marked by the beginning of the charcoal peak (e.g., Long et al. 1998, Millspaugh et al. 2000), we conservatively identified fire episodes as the entire time span of the peak (i.e., the time when the threshold ratio was 


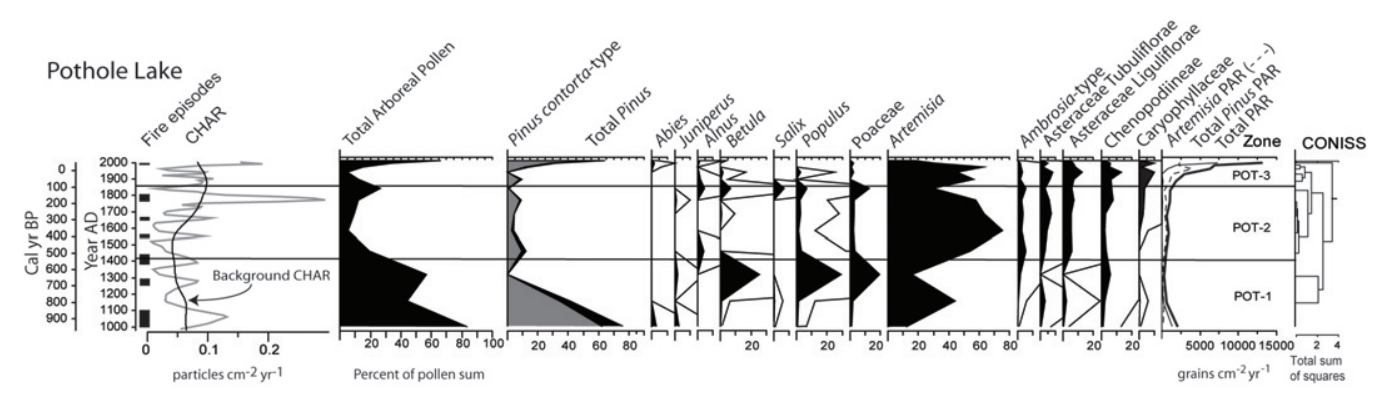

Fig. 4. Charcoal and pollen records of the last 990 years at Pothole Lake (see Fig. 3 for explanation).

first exceeded to the time when CHAR values dropped below the ratio). With our approach, fire episodes were decades long and considered to be periods of high fire activity rather than single fire events.

The average resolution of the Hedrick Pond charcoal record was approximately $17.5 \mathrm{yr}$. $\mathrm{cm}^{-1}$. BCHAR ranged between 0.22 and 0.13 particles $\cdot \mathrm{cm}^{-2} \mathrm{yr}^{-1}$ (Fig. 3). In the last $500 \mathrm{cal}$ yr, background CHAR decreased from about 0.20 to $\sim 0.1$ particles $\cdot \mathrm{cm}^{-2} \mathrm{yr}^{-1}$. In the last $900 \mathrm{cal} \mathrm{yr}$, fire episodes, i.e., charcoal peaks above the threshold, were relatively infrequent, and several spanned long intervals. Episodes occurred between AD 1980 and 2000 (-30 to $-50 \mathrm{cal} \mathrm{yr} \mathrm{BP}), \mathrm{AD} 1780$ and $1850(170-100 \mathrm{cal}$ yr BP), AD 1740 and 1750 (210-200 cal yr BP), AD 1540 and 1550 (410-400 cal yr BP), AD 1400 and $1500(550-450 \mathrm{cal} \mathrm{yr} \mathrm{BP})$, and AD 1060 and 1150 (890-800 cal yr BP). Prior to that, fire episodes were more frequent and spanned shorter intervals. Older episodes were recorded at 1020-1040, 1160-1180, 1210-1230, 1250-1280, 1380-1420, 1570-1610, 1640-1730, 1910-2000, 2070, and 2110-2120 cal yr вP.

At Pothole Lake the deposition time for each sample was approximately $27.2 \mathrm{yr} \cdot \mathrm{cm}^{-1}$. BCHAR was low, ranging from 0.02 to 0.09 particles $\cdot \mathrm{cm}^{-2} \mathrm{yr}^{-1}$. A large peak in CHAR (0.29 particles $\cdot \mathrm{cm}^{-2} \mathrm{yr}^{-1}$ ) occurred at ca. $\mathrm{AD}$ 1800 (ca. 150 cal yr BP; Fig. 4). Fire episodes in the last 400 cal $\mathrm{yr}$ were dated from $\mathrm{AD}$ $1980-2000$ ( -30 to -50 cal yr BP), AD 17601810 (190-140 cal yr BP), AD 1650-1670 (300280 cal yr BP), and AD 1550-1570 (400-380 cal $\mathrm{yr}$ BP). Earlier episodes occurred at $\mathrm{AD}$ 1390-1450 (560-500 cal yr BP), AD 12601300 (690-650 cal yr BP), and AD 1010-1110 (940-840 cal yr вP).

The Swan Lake charcoal record had a sampling resolution of approximately $9.6 \mathrm{yr} \cdot \mathrm{cm}^{-1}$.
BCHAR levels were highest at AD $1400(550$ cal уr вр; 1.09 particle $\left.\cdot \mathrm{cm}^{-2} \mathrm{yr}^{-1}\right)$ and declined from AD 1400 to 1750 (550 to $200 \mathrm{cal} \mathrm{yr}$ вP) to $\sim 1$ particle $\cdot \mathrm{cm}^{-2} \mathrm{yr}^{-1}$ and decreased to $\sim 0.3$ particles $\cdot \mathrm{cm}^{-2} \mathrm{yr}^{-1}$ at present (Fig.4). Fire episodes occurred at AD 1980-2000 (-30 to -50 cal yr BP), AD 1920 (30 cal yr BP), AD 1860-1870 (90-80 cal yr BP), AD 1770-1830 (180-120 cal yr вP), AD 1550-1560 (400-390 cal yr BP), AD 1460-1520 (490-430 cal yr BP), and AD 1420-1430 (530-520 cal yr BP).

Pollen Records

Hedrick Pond (Fig. 3).-Average spacing between pollen samples in the Hedrick Pond core was 60 years. Zone HED-1 (86-137 cm depth; ca. 960-2130 cal yr вр) featured high percentages of Pinus (mostly P. contorta-type; 47\%-52\%), Artemisia (20\%-30\%), and Poaceae (grass family; 5\%-10\%). Picea, Abies, Juniperus, Salix, Chenopodiineae (goosefoot and amaranth families), and Ambrosia-type (ragweed) were present in low amounts $(<5 \%)$. Total PAR averaged 1350 grains $\cdot \mathrm{cm}^{-2} \mathrm{yr}^{-1}$, and these values and the percentage data suggest that vegetation was more open than at present (Fall 1992, Whitlock 1993).

Zone HED-2 (20-82 cm depth; 90-960 cal yr BP; AD 1860-990) was characterized by increasing Pinus percentages (55\%-84\%) and decreasing Artemisia values (24\%-10\%). Pinus flexilis-type decreased toward the top of this zone while $P$. contorta-type increased. Picea occurred at its highest percentages but still in low values (<4\%). Abies-, Salix-, and Ambrosiatype pollens were present in small amounts $(<2 \%)$. Poaceae percentages were lower than in the previous zone $(<6 \%)$. Juniperus-type pollen was present in low percentages at the beginning of this zone (up to $1 \%$ ) and disappeared at ca. AD 1770. Total PAR increased 


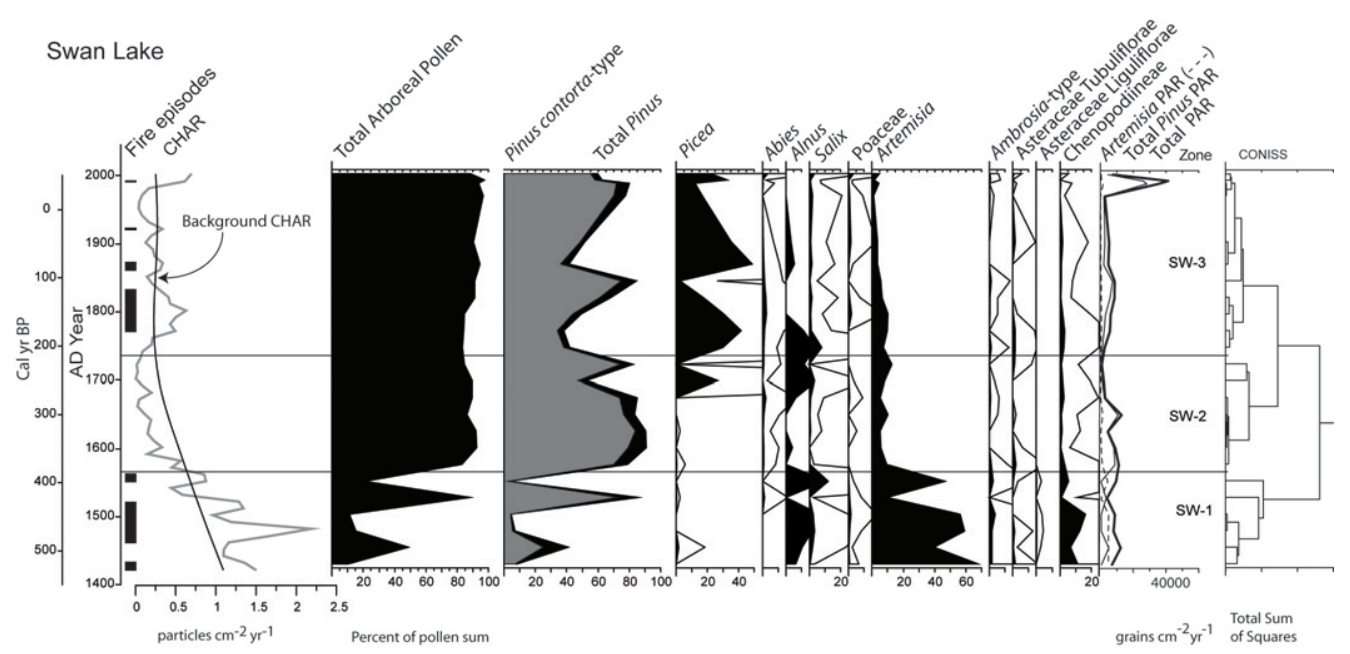

Fig. 5. Charcoal and pollen records of the last 550 years at Swan Lake (see Fig. 3 for explanation).

from previous values, and the combination of high Pinus percentages, moderately high Artemisia percentages, and low Picea percentages is consistent with the modern pollen assemblages from lodgepole pine forest in GTNP (Whitlock 1993). It suggests an increase in forest cover near the site.

Zone HED-3 (0-20 cm depth; present-90 cal yr BP; AD 2005-1860) featured a peak in Pinus percentages $(85 \%)$ and PAR (5700 grains . $\mathrm{cm}^{-2} \mathrm{yr}^{-1}$ ) at ca. AD 1900. The uppermost samples returned to high percentages of Artemisia $(\sim 30 \%)$, Ambrosia-type (1\%-2\%), and moderate percentages of Pinus $(\sim 60 \%)$. The percentages in this zone fall within the range of those from dry, low-elevation forests in the GTNP region (Whitlock 1993), and the assemblage is consistent with the modern presence of forested and open communities at the site.

Pothole LaKe (Fig. 4).--Average spacing between pollen samples in the Pothole Lake core was 125 years. Zone POT-1 (40-48 cm depth; 550-990 cal yr BP; AD 1400-960) had decreasing percentages of Pinus $(80 \%$ at the base to $40 \%$ at the top of the zone) and increasing values of Artemisia (12\% at the base to $44 \%$ at the top). Abies values declined to zero in the middle of this zone, and Poaceae values peaked at $20 \%$ near the end of this zone. Pollen of Betula and Populus were high (20\% and $29 \%$, respectively) near the end of the zone at $40 \mathrm{~cm}$ depth. Other pollen taxa, including Juniperus-type $(<2 \%)$, Ambrosia-type, other Asteraceae Tubuliflorae, Asteraceae Liguliflorae,
Caryophyllaceae, and Chenopodiineae, were poorly represented $(<8 \%)$. Total PAR was low at an average of 1130 grains $\cdot \mathrm{cm}^{-2} \mathrm{yr}^{-1}$ and similar to modern values from sagebrush steppe (Fall 1992).

Zone POT-2 (16-40 cm depth; 60-550 cal yr BP; AD 1890-1400) was characterized by a dominance of Artemisia with values up to $80 \%$. Pinus percentages were very low with values consistently $<20 \%$. Abies pollen was not present in this zone, and Juniperus, Alnus, Betula, and Salix pollen occurred in small amounts (<5\%). Ambrosia-type, Asteraceae Tubuliflorae and Liguliflorae, and Chenopodiineae pollen were present in slightly higher amounts $(<10 \%)$ than before. Total PAR was low, at an average of 800 grains $\cdot \mathrm{cm}^{-2} \mathrm{yr}^{-1}$, which is consistent with values for sagebrush steppe in the region (Fall 1992).

Zone POT-3 (0-16 cm depth; present-60 cal yr BP; AD 2005-1890) featured a sharp increase in Pinus (70\%) and the reappearance of Abies pollen (also present in the lowest sample of Zone POT-1) in the uppermost sample. At other levels, Artemisia (18\%-60\%), Ambrosiatype (1\%-3\%), other Asteraceae (2\%-8\%), and Chenopodiineae $(2 \%-13 \%)$ were high, and Caryophyllaceae percentages were highest $(\sim 12 \%)$ in this zone. PAR reached highest values, ranging from 6000 to 13,000 grains $\cdot \mathrm{cm}^{-2}$ year ${ }^{-1}$ at the top. The dominance of Artemisia and other herbs, as in Zone POT-2, is similar to the modern pollen rain from steppe communities in the region (Whitlock 1993). 
Swan LaKe (FIg. 5).-The average spacing of pollen samples in the Swan Lake core was 27 years. Zone SW-1 (53-73 cm depth; 375520 cal yr BP; AD 1575-1430) was dominated by Artemisia (15\%-70\%) and had moderate percentages of Alnus (1\%-3\%), Salix (1\%$12 \%)$, and Chenopodiineae (3\%-16\%). Percentages of Pinus, largely from P. contorta-type, were low $(<25 \%)$, except for 1 high interval $(85 \%)$ at $59 \mathrm{~cm}$ depth. Picea and Abies were present in low amounts $(<2 \%)$. Ambrosia-type reached its highest amounts (up to 4\%) in this zone, and Asteraceae Liguliflorae was present in trace amounts $(<1 \%)$. Total PAR ranged from 4000 to 12,000 grains $\cdot \mathrm{cm}^{-2}$ year-1, which is consistent with other steppe areas (Fall 1992); Artemisia percentages were somewhat higher than those from modern steppe in GTNP (ca. 12\%-25\%; Whitlock 1993).

Zone SW-2 (35-53 cm depth; 220-375 cal yr BP; AD 1730-1575) featured the highest Pinus percentages $(52 \%-90 \%)$ of the record. Artemisia and Chenopodiineae percentages dropped from the previous zone (to $<14 \%$ and $<4 \%$, respectively). Total PAR did not change appreciably from the previous zone. Pinus contorta-type percentages (42\%-78\%) were equal to or higher than modern values from pine forests in GTNP (Whitlock 1993).

Zone SW-3 (0-35 cm depth; present-220 cal yr BP; AD 2005-1730) was characterized by alternating peaks of Pinus and Picea percentages. Total Pinus percentages ranged between $40 \%$ and $80 \%$, and Picea percentages ranged between $0 \%$ and $50 \%$. Abies pollen was present through this zone in low amounts $(<2 \%)$. Artemisia percentages declined from $12 \%$ at the base of the zone to $3 \%$ at the top. The top 2 samples (AD 1993-present) showed a slight decrease in total Pinus (59\%-55\%) and a peak in Picea (to 32\%), Abies (to 3\%), Salix (to 3\%), and Poaceae (to 3\%). Total PAR changed little in this zone, except for a peak near AD 1980 of 41,000 grains $\cdot \mathrm{cm}^{-2} \mathrm{yr}^{-1}$, which is largely a result of an increase in Pinus PAR at 28,000 grains $\cdot \mathrm{cm}^{-2} \mathrm{yr}^{-1}$.

\section{Discussion}

\section{Environmental History in Jackson Hole}

We compared the local vegetation and fire histories (Figs. 3, 4, and 5) to develop a better understanding of the environmental history of Jackson Hole. In addition to the stratigraphic trends of individual pollen types, trends in the arboreal pollen percentages (AP) and PAR help disclose the relative importance of forest over steppe taxa through time (Whitlock and Bartlein 1997). Hedrick Pond provides information on the entire 2100-year period, Pothole Lake spans the last approximately $1000 \mathrm{cal}$ yrs, and Swan Lake data cover the last $550 \mathrm{cal}$ yrs.

Persistent high values of Pinus and Artemisia pollen at Hedrick Pond show little change (with the exception of a single sample), and it seems likely that the mix of forest and steppe communities at this site has not changed substantially in the last 2100 years. The slightly lower AP before AD 970 implies that there was somewhat more open vegetation than at present, and in the last 1000 years forest cover has apparently increased. This trend toward more forest cover has been noted at other sites in the region and may be part of a shift toward cooler, wetter conditions during the late Holocene (Whitlock 1993). The sharp increase of Pinus at ca. AD 1900 is based on a single sample and not easily interpreted, but it comes after several fires in the 19th century and may be related to forest regeneration.

The pollen records from Pothole and Swan lakes, in contrast, indicate significant changes in local vegetation that are probably a response to shifts in hydrology. Pothole Lake apparently has had a history of fluctuating water levels, and it was dry or only seasonally wet prior to ca. AD 960, the beginning of our record. AP values, mostly from Pinus, were initially high, although Pinus PAR was low and some grains were degraded, which is consistent with an initially dry basin. As the site became wetter, sediments became more organic and limnic, and percentages of Artemisia pollen increased between ca. AD 1100 and 1890. It seems likely that this increase marked a shift to a local steppe pollen source as the lake developed, rather than a vegetation change. Notable increases in Betula, Populus, and Poaceae pollen occurred at ca. AD 1300 and at AD 1820, suggesting brief wet periods that increased the representation of mesophytic taxa. Pothole and Swan Lakes show an increase in conifers in the late 20th century.

The Swan Lake area supported sagebrush steppe with Chenopodiineae between AD 1430 and 1575 , as indicated by low AP percentages, high values of Artemisia (Fig. 5), and evidence of riparian communities of Alnus and Salix. By 


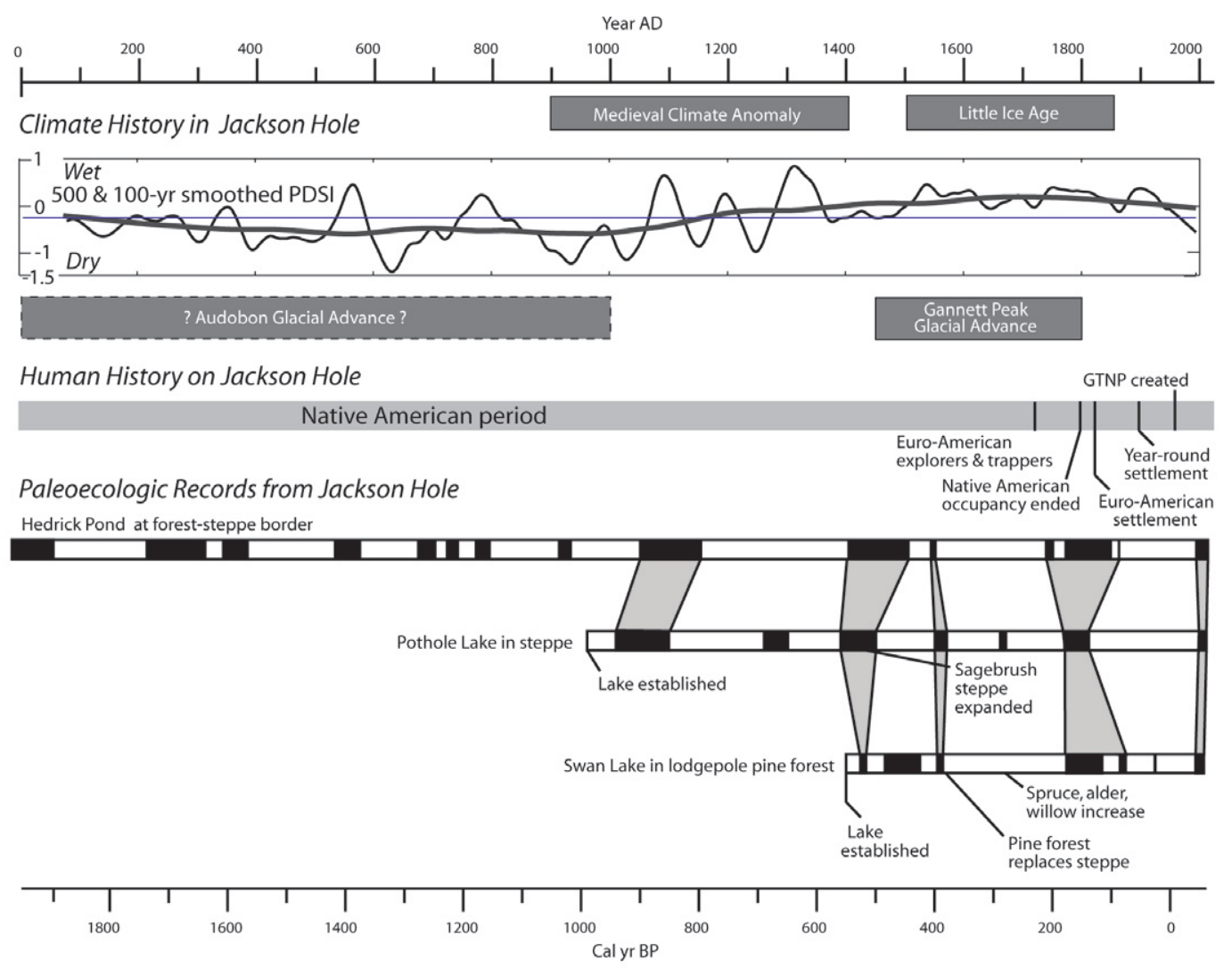

Fig. 6. Timeline of climate events, human impacts, and important periods in Jackson Hole (see text for discussion). The PDSI data for gridpoint 100 of Cook et al. (2004) are smoothed with moving 100-year and 500-year window widths to show centennial and longer time variations in effective moisture. Fire episodes at each site (black bars) and correlation (gray shading) among charcoal records are indicated.

ca. AD 1575, Artemisia decreased and Pinus increased, marking a shift from steppe to more closed lodgepole pine forest. Picea, Alnus, and Salix percentages increased after ca. AD 1670 , and their abundance has fluctuated in recent centuries. These taxa grow in riparian forest along Pilgrim Creek, and fluctuations in their pollen abundance may signify short-term changes in hydrology related to climate.

Over the last 550 years, all 3 sites indicate periods of fire at AD 1980-2000, 1780-1810, ca. 1550, and 1420-1430. Hedrick Pond and Pothole Lake were also compared for the previous $450 \mathrm{cal}$ yrs of overlap and shared a broad period of high fire activity from $\mathrm{AD} 1060$ to 1110 (Fig. 6). Recent fire episodes at these sites match known fire events registered in tree-ring and historical records. For example, fires were widespread in and around Jackson Hole in the 1980s, including large fires in 1986 and 1988 (Grand Teton National Park Fire Management Office, unpublished report, 2006). Tree-ring records identify several fire years in Jackson Hole in the early to mid-19th century (Loope 1974), including those in the 1880s, $1870 \mathrm{~s}, 1850 \mathrm{~s}$, and late 1700s south of Jackson Lake. Some of these dates match fires registered at Pothole Lake and Hedrick Pond (Figs. 2 and 3). Tree-ring records also indicate fires in the Colter Bay area near Swan Lake in the 1850 s, and these are a likely source for charcoal peaks at about that time. A tree-ring fire date at ca. AD 1910 (Loope 1974) was not found in the charcoal record, and other fire episodes at Swan Lake in AD 1770-1830 and ca. AD 1920 are not evident in the tree-ring record (Fig. 4).

\section{Climate and Human Influences}

Pollen and charcoal records were compared with widely recognized climate events in the 
Rocky Mountain region (Fig. 6). The Medieval Climate Anomaly (MCA) between ca. AD 800 and 1300 was a period of low average precipitation and widespread drought in the western United States (Cook et al. 2004). The Little Ice Age (LIA) in the northern Rocky Mountains was a time of cooler conditions and renewed glacial activity between $\mathrm{AD} 1300$ and 1900 that culminated between AD 1700 and 1900 (Carrara 1989, Luckman 2000). The Gannett Peak cirque glacial advance in the Teton Range dates between ca. AD 1450 and 1800 and is considered an LIA event. A poorly dated Audubon advance, however, occurred before ca. AD 1000 (Mahaney and Spence 1990).

The reconstructed Palmer Drought Severity Index (PDSI) of Cook et al. (2004), which is based on a compilation of long tree-ring chronologies throughout the United States, offers additional information on variations in effective moisture during the last 2000 years. Gridpoint 100 in the PDSI reconstruction from the GTNP region was used for comparison (Fig. 6). Although variability on interannual to decadal time scales is considerable, the PDSI data, smoothed at 100-year and 500-year times, showed trends that are relevant to this study. A prolonged dry period in this region extended from ca. AD 0 to 1200 , while the "classic" MCA occurred at the end of this period during a time of high moisture variability. Positive values (wet) extended from ca. AD 1200 to 1900, and the LIA was part of a sustained wet period within this period. Thus, both MCA and LIA are somewhat different in duration and signal at this gridpoint than elsewhere in the West.

Hedrick Pond data suggest shorter and more frequent fire episodes prior to $1200 \mathrm{cal} \mathrm{yr} \mathrm{BP}$, when conditions were drier than afterwards. On shorter time scales, several fire episodes occurred during wet century-long periods, for example, centered around ca. AD 550, 790, 1100,1300 , and 1800 . This relationship between fire and wet periods has been described in sagebrush steppe elsewhere in the western United States (e.g., Mensing et al. 2006), and it is possible that wet decades increased the fine-fuel biomass, which then ignited during brief periods of drought (Tirmenstein 1999).

Swan Lake was formed near the beginning of the LIA, when the alluvial fan from Pilgrim Creek blocked its outlet. The period from ca. AD 1430 to 1575 featured 3 broad fire episodes and more extensive steppe vegetation than at present. Lodgepole pine forest dominated after AD 1575, and riparian forest developed after AD 1670, accounting for the rise in AP values (Fig. 5). Fire episodes throughout this record were associated with drops in Pinus percentages, suggesting that the local forest was the primary fuel.

Concurrent fire activity at all 3 sites in the past raises the possibility that humans were a source of ignitions (Barrett and Arno 1982, Baker and Ehle 2001, Keely 2002). Native Americans have inhabited Jackson Hole for the last 10,000 years, with the oldest records dated by projectile point type (Connor 1998; Fig. 6). Archaeological sites with roasting pits and concentrations of lithic artifacts of Holocene age are found throughout the valley. Season of occupancy, inferred from the type of roasting pits, associated utensils, and food remnants (Connor 1998), indicates that the northern valley was heavily occupied in the late summer and fall from $\mathrm{AD} 0$ to 1150 , when the number of roasting pits reached a maximum. Between AD 1150 and 1750, more sites were found in southern Jackson Hole than before, although few were roasting pits. These later southern sites are thought to have been used in the spring and summer when food processing and storage were less important activities (Connor 1998). The Hedrick Pond record does not show a corresponding change in fire activity that might be expected with an increase in Native American occupancy of the southern region. In fact, none of the charcoal and pollen records offer evidence that could unequivocally be attributed to temporal or spatial changes in Native American use of the valley.

Trappers and fur traders entered Jackson Hole in the early 19th century (Daugherty 1999) and may have been the 1st Europeans to alter the fire regime. John Colter, a member of the Lewis and Clark Expedition, was allegedly the 1st white man to travel through Jackson Hole in 1807. A group representing John Jacob Astor's fur trading company passed through the valley in 1811, and the Tetons became a major landmark for trappers in the Greater Yellowstone area for the next 30 years. In 1860 a military expedition under the leadership of Captain W.F. Raynolds entered Jackson Hole as the first of 3 military surveys to pass through the area. Photographs taken by William Henry Jackson during the 1872 Hayden survey 
expedition show burned forest stands, and burned forest was described in journal entries from the surveys in 1872 and 1877 (Daugherty 1999).

Miners in the 1860s and 1870s panned nearly every stream in the valley, with little success. Elaborate placer mines were set up on Pilgrim Creek above Swan Lake (Daugherty 1999). Fire episodes at that site in the mid1800s fall within this period, although it is not possible to determine their cause. Homesteaders arrived in AD 1884 and inhabited Jackson Hole year-round. According to the 1900 census (Census of the United States 1900, Jackson Precinct; Daugherty 1999), 638 people lived in the valley, including the towns of Jackson, Moran, and Kelly; the numbers of settlers steadily increased after AD 1900 (Daugherty 1999). Farmers and ranchers settled mainly in the southern valley near the town of Jackson, where they planted oats, barley, wheat, and alfalfa on cleared and burned sagebrush steppe (Daugherty 1999). Pollen records show a few grains from nonnative taxa at the top (Rumex, Plantago; Whitlock 1993), but no major changes. The charcoal records also provide no evidence of a change in fire frequency during the settlement period.

The most notable change in the pollen records at Pothole and Swan Lakes is the increase in Pinus and other conifers in the 20th century. Photographic comparisons between the late 19th century and present, for example, indicate that low-elevation forest in many parts of the Grand Teton and Yellowstone region has become denser within the last $\sim 100$ years (Arno and Gruell 1983, Meagher and Houston 1998). These photos document a trend that has been noted throughout the West and attributed to the effects of fire elimination and grazing (Savage 1991, Veblen and Lorenz 1991, Miller and Wigand 1994). It is likely that such changes in GTNP are also the direct or indirect result of fire-suppression policies and other land-use changes.

\section{Conclusions}

The pollen and charcoal records from 3 sites in Jackson Hole provide information on environmental changes at low elevations in Grand Teton National Park that can be compared with paleoclimatic, archaeologic, and historic data from the region. The vegetation his- tory suggests little change other than that related to local hydrology. The charcoal record indicates a decrease in fire frequency at $\mathrm{AD}$ 1200 that is likely related to the long-term increase in effective moisture shown by PDSI reconstructions. At Hedrick Pond high fire activity is consistent with drier-than-present conditions prior to AD 1200. Since then, the records show a response to increasingly wet conditions through changes in hydrology, vegetation, and fire regime. The comparison of charcoal records over the last 550 cal yrs suggests intervals of high fire activity at all sites in AD 1980-2000, 1780-1810, ca. 1550, and 14201430. These may have been caused by human activity, but the charcoal records do show temporal patterns to match shifts in human occupancy inferred from the archaeological record. More recent fires may have been set by EuroAmericans who actively mined and ranched in the region, but our data are inconclusive on this. The increase in forest cover in recent decades, seen at 2 of our sites, is noted throughout the region and may result from the combined effects of climate change and land-use practices.

\section{ACKNOWLEDGMENTS}

This research was funded by a grant from the University of Wyoming-National Park Service Research Center and a Cooperative Agreement from the RM-CESU Program (National Park Service 1249-FET5H114). We thank Sue Consolo Murphy and Kelly McCloskey of Grand Teton National Park for their support on this project. Ken Pierce provided many helpful insights concerning the Quaternary history of the region. We also thank Christy Briles, Danny Jacobs, Josh Gage, Bob Hickey, Ben White, Marianne White, and Mariana Huerta for help in the field and laboratory.

\section{Literature Cited}

Arno, S.F., And G.E. Gruell. 1983. Fire history at the forest-grassland ecotone in southwestern Montana. Journal of Range Management 36:332-336.

BAKER, R.G. 1976. Late Quaternary vegetation history of the Yellowstone Lake Basin, Wyoming. U.S. Geological Survey Professional Paper 729-E:E1-E48.

BAKER, W.L., AND D. EHLE. 2001. Uncertainty in surface fire history: the case of ponderosa pine forests in the western United States. Canadian Journal of Forest Research 31:1205-1226. 
Barrett, S.W., And S.F. ARNo. 1982. Indian fires as an ecological influence in the Northern Rockies. Journal of Forestry 80:647-651.

Carrara, P.E. 1989. Late Quaternary glacial and vegetative history of the Glacier National Park region, Montana. U.S. Geological Survey Bulletin 1902:1-64.

Clark, T.W. 1981. Ecology of Jackson Hole, Wyoming. Paragon Press, Salt Lake City, UT.

Connor, M.A. 1998. Final report on the Jackson Lake Archaeological Project, Grand Teton National Park, Wyoming. Midwest Archaeological Center Technical Report 33, Lincoln, NE.

Cook, E.R., C.A. Woodhouse, C.M. Eakin, D.M. Meko, AND D.W. STAHLE. 2004. Long-term aridity changes in the western United States. Science 306:10151018.

DAugherTy, J. 1999. A place called Jackson Hole: a historic resource study of Grand Teton National Park. Grand Teton Natural History Association, Moose, WY.

DEAN, W.E., JR. 1974. Determination of carbonate and organic matter in calcareous sediments by loss on ignition, comparison to other methods. Journal of Sedimentary Petrology 44:242-248.

DoHer, L.I. 1980. Palynomorph preparation procedures currently used in the paleontology and stratigraphy laboratories, U.S. Geological Survey. Geological Survey Circular 830.

Faegri, K., P.E. Kaland, and K. Kzywinski. 1989. Textbook of pollen analysis. Wiley, New York.

FALL, P.L. 1992. Spatial patterns of atmospheric pollen dispersal in the Colorado Rocky Mountains, USA. Review of Paleobotany and Palynology 74:293-313.

Good, J.M., AND K.L. Pierce. 1996. Interpreting the landscapes of Grand Teton and Yellowstone National Park: recent and ongoing geology. Grand Teton Natural History Association, Moose, WY.

Grimm, E.C. 1987. CONISS: a Fortran 77 program for stratigraphically constrained cluster analysis by the method of incremental sum of squares. Computers \& Geosciences 13:13-35.

Hughes, M.K., And H.F. Diaz. 1994. Was there a 'Medieval Warm Period', and if so, where and when? Climatic Change 26:109-142.

Kapp, R.O., O.K. Davis, and J.E. King. 2000. Pollen and spores. American Association of Stratigraphic Palynologists, Texas A\&M University, College Station.

KeELY, J.E. 2002. Native American impacts on fire regimes of the California coastal ranges. Journal of Biogeography 29:303-320.

Long, C.J., C. Whitlock, P.J. Bartlein, and S.H. MillSPAUGH. 1998. A 9000-year fire history from the Oregon Coast Range, based on a high-resolution charcoal study. Canadian Journal of Forestry 28:774-787.

Loope, L.L. 1974. Fire history investigations in Grand Teton National Park. Unpublished agency report.

LUCKMAN, B.H. 1994. Glacier fluctuation and tree-ring records for the last millennium in the Canadian Rockies. Quaternary Science Reviews 12:441-450.

2000. The Little Ice Age in the Canadian Rockies. Geomorphology 32:357-394.

Mahaney, W.C., AND J.R. SPEnCE. 1990. Neoglacial chronology and floristics in the Middle Teton area, central Teton Range, western Wyoming. Journal of Quaternary Science 5:53-66.

Marlon, J., P.J. Bartlein, And C. Whitlock. 2006. Firefuel-climate linkages in the northwestern U.S. during the Holocene. The Holocene 16:1059-1071.
McKenzie, D., Z. Gedalof, D.L. Peterson, and P. Mote. 2004. Climate change, wildfire, and conservation. Conservation Biology 18:890-902.

Meagher, M., And D.B. Houston. 1998. Yellowstone and the biology of time: photographs across a century. University of Oklahoma Press, Norman.

Mensing, S., S. Livingston, And P. Barker. 2006. Longterm fire history in Great Basin sagebrush reconstructed from macroscopic charcoal in spring sediments, Newark Valley, Nevada. Western North American Naturalist 66:64-77.

Miller, R.F., AND P.E. Wigand. 1994. Holocene changes in semiarid pinyon-juniper woodlands: response to climate, fire, and human activities in the U.S. Great Basin. BioScience 44:465-474.

Millspaugh, S.H., AND C. Whitlock. 1995. A 750-year fire history based on lake sediment records in central Yellowstone National Park. The Holocene 5:283-292.

Millspaugh, S.H., C. Whitlock, and P.J. Bartlein. 2000. Variations in fire frequency and climate over the past $17000 \mathrm{yr}$ in central Yellowstone National Park. Geology 28:211-214.

Moore, P.O., AND J.A. WEBB. 1978. An illustrated guide to pollen analysis. Wiley, New York.

Pierce, J.L., G.A. Meyer, And A.J.T. Jull. 2004. Fireinduced erosion and millennial scale climate change in northern ponderosa pine forests. Nature 432:8790.

Pierce, K.L. 2004. Pleistocene glaciations of the Rocky Mountains. Developments in Quaternary Science 1: 63-76.

SAVAGE, M.A. 1991. Structural dynamics of a southwestern pine forest under chronic human influence. Annals of the Association of American Geographers 81:271289.

Shaw, R.J. 2000. Plants of Yellowstone and Grand Teton National Parks. Wheelwright Press, Salt Lake City, UT.

Stuiver, M., P.J. Reimer, and T.F. Braziunas. 1998. Highprecision radiocarbon age calibration for terrestrial and marine samples. Radiocarbon 40:1127-1151.

Thompson, R., And F. OLdField. 1986. Environmental magnetism. Allen \& Unwin, London.

Tirmenstein, D. 1999. Artemisia tridentata spp. tridentata. In: Fire Effects Information System [online], U.S. Department of Agriculture, Forest Service, Rocky Mountain Research Station, Fire Sciences Laboratory (producer). Available from: http://www.fs.fed.us/ database/feis

Veblen, T., And D. Lorenz. 1991. The Colorado Front Range: a century of ecological change. University of Utah Press, Salt Lake City.

Westerling, A.L., H.G. Hidalgo, D.R. Cayan, and T.W. SWETNAM. 2006. Warming and earlier spring increases in western U.S. forest wildfire activity. Science 313: 940-943.

Whitlock, C. 1993. Postglacial vegetation and climate of Grand Teton and southern Yellowstone National Parks. Ecological Monographs 63:173-198.

Whitlock, C., AND P.J. Bartlein. 1997. Vegetation and climate change in northwest America during the past 125 kyr. Nature 388:57-61.

Whitlock, C., and C. Larsen. 2001. Charcoal as a fire proxy. Pages 75-97 in J.P. Smol, H.J.B Birks, and W.M. Last, editors, Tracking environmental change using 
lake sediments. Volume 3. Terrestrial, algal, and siliceous indicators. Kluwer Academic Publishers, Dordrecht, The Netherlands.

Whitlock, C., S.H. ShafER, AND J. MarLON. 2003. The role of climate and vegetation change in shaping past and future fire regimes in the northwestern U.S., and the implications for ecosystem management. Forest Ecology and Management 178:5-21.
Wright, Jr., H.E., D.H. ManN, and P.H. Glaser. 1983. Piston cores for peat and lake sediments. Ecology 65:657-659.

Received 21 September 2007 Accepted 6 March 2008 